Marquette University

e-Publications@Marquette

Biological Sciences Faculty Research and

Publications

Biological Sciences, Department of

$5-2013$

\title{
Increasing Liana Abundance and Basal Area in a Tropical Forest: The Contribution of Long-distance Clonal Colonization
}

\author{
Suzanne R. Yorke \\ University of Wisconsin - Milwaukee \\ Stefan A. Schnitzer \\ Marquette University, stefan.schnitzer@marquette.edu \\ Joseph Mascaro \\ University of Wisconsin - Milwaukee \\ Susan G. Letcher \\ Purchase College \\ Walter P. Carson \\ University of Pittsburgh
}

Follow this and additional works at: https://epublications.marquette.edu/bio_fac

Part of the Biology Commons

\section{Recommended Citation}

Yorke, Suzanne R.; Schnitzer, Stefan A.; Mascaro, Joseph; Letcher, Susan G.; and Carson, Walter P., "Increasing Liana Abundance and Basal Area in a Tropical Forest: The Contribution of Long-distance Clonal Colonization" (2013). Biological Sciences Faculty Research and Publications. 720.

https://epublications.marquette.edu/bio_fac/720 
Marquette University

e-Publications@Marquette

\section{Biology Faculty Research and Publications/College of Arts and Sciences}

This paper is NOT THE PUBLISHED VERSION; but the author's final, peer-reviewed manuscript. The published version may be accessed by following the link in the citation below.

Biotropica, Vol. 45, No. 3 (May, 2013): 317-324. DOI. This article is (C) Wiley and permission has been granted for this version to appear in e-Publications@Marquette. Wiley does not grant permission for this article to be further copied/distributed or hosted elsewhere without the express permission from Wiley.

\section{Increasing Liana Abundance and Basal Area in a Tropical Forest: The Contribution of Long- distance Clonal Colonization}

Suzanne R. Yorke

Department of Biological Sciences, University of Wisconsin-Milwaukee, WI

Stefan A. Schnitzer

Department of Biological Sciences, University of Wisconsin-Milwaukee, WI

Smithsonian Tropical Research Institute, Apartado Postal 0843-03092, Ancon, Panama, Republic of Panama

Joseph Mascaro

Department of Biological Sciences, University of Wisconsin-Milwaukee, WI

Smithsonian Tropical Research Institute, Apartado Postal 0843-03092, Ancon, Panama, Republic of Panama

Susan G. Letcher

Department of Environmental Studies, Purchase College (SUNY), 735 Andersonal Hill Road, Purchase, NY

Walter P. Carson

Department of Biological Sciences, University of Pittsburgh, Pittsburgh, PA 


\section{Abstract}

Recent evidence suggests that liana abundance and biomass are increasing in Neotropical forests, representing a major structural change to tropical ecosystems. Explanations for these increases, however, remain largely untested. Over an 8-yr period (1999-2007), we censused lianas in nine, $24 \times 36 \mathrm{~m}$ permanent plots in oldgrowth and selectively logged forest at La Selva Biological Station, Costa Rica to test whether: (1) liana abundance and basal area are increasing in this forest; (2) the increase is being driven by increased recruitment, decreased mortality, or both; and (3) long-distance clonal colonization explains the increase in liana abundance and basal area. We defined long-distance clonal colonization as lianas that entered and rooted in the plots as vegetative propagules of stems that originated from outside or above the plot, and were present in 2007, but not in 1999 or 2002. Our hypotheses were supported in the old-growth forest: mean liana abundance and BA ( $\geq 1 \mathrm{~cm}$ diameter) increased 15 and 20 percent, respectively, and clonal colonization from outside of the plots contributed 19 and 60 percent (respectively) to these increases. Lianas colonized clonally by falling vertically from the forest canopy above or growing horizontally along the forest floor and re-rooting-common forms of colonization for many liana species. In the selectively logged forest, liana abundance and BA did not change, and thus the pattern of increasing lianas may be restricted to old-growth forests. In summary, our data support the hypothesis that lianas are increasing in old-growth forests, and that long-distance clonal colonization is a major contributor.

Lianas (woody vines) are an important component of tropical forests, comprising 10-45 percent of woody plant individuals and species (Schnitzer \& Bongers [34] ), and playing a major role in tropical forest dynamics. Lianas reduce tree recruitment, regeneration, growth, fecundity, and survival (Schnitzer et al. [37] , [39] , ToledoAceves \& Swaine [46] , Ingwell et al. [18] , Schnitzer \& Carson [36] ). In addition, lianas may shape tree community composition via competitive interactions because lianas are deleterious to shade-tolerant trees, but have little effect on pioneer trees (Putz [30], Clark \& Clark [5] , Schnitzer et al. [37] , Schnitzer \& Carson [36] ). Recent evidence indicates that, relative to trees, lianas are increasing in abundance, biomass, productivity, and fecundity in Neotropical and subtropical forests (reviewed by Schnitzer \& Bongers [35] ). For example, liana increases have been reported in the Central Amazon (Phillips et al. [29] , Benítez-Malvido \& Martínez-Ramos [2] ), the Bolivian Amazon (Phillips et al. [29] , Foster et al. [11] ), French Guiana (Chave et al. [4] ), and in central Panama (Wright et al. [48], Ingwell et al. [18] ).

Because of the negative impacts of lianas on trees, higher liana abundance and biomass may substantially alter tropical forest composition and dynamics, as well as important ecosystem-level attributes (reviewed by Schnitzer \& Bongers [35] , Schnitzer et al. [43] ). For example, lianas may lower whole-forest carbon storage by reducing tree growth and increasing tree mortality, especially for shade-tolerant trees with high wood density. Because liana stems contain far less carbon than trees, lianas do not compensate for the tree biomass that they displace (e.g., van der Heijden \& Phillips [16] , Schnitzer \& Bongers [35] , Tobin et al. [45] ).

The leading hypotheses to explain liana increases include increasing forest disturbance, increasing duration and severity of seasonal drought, and elevated atmospheric $\mathrm{CO}_{2}$-all of which may be operating simultaneously and synergistically (Schnitzer \& Bongers [35] ). Increasing forest disturbance would favor lianas relative to trees by creating more edge and gap habitat, where lianas proliferate (Putz [30], Schnitzer et al. [37] , Schnitzer \& Carson [36] , Dalling et al. [7] ). Stronger seasonal drought may benefit lianas because they suffer less water stress and grow more than trees during dry periods (Schnitzer [33] , Cai et al. [3] , Zhu \& Cao [49] ), presumably increasing their fecundity, abundance, and biomass relative to trees. Stronger seasonal drought has been linked to decreases in tree density and increases in liana density in both tropical dry and moist forests (Ingwell et al. [18] , Enquist \& Enquist [10] ), as well as decreases in tree growth in tropical wet forests (Clark et al. [6] ). Elevated atmospheric $\mathrm{CO}_{2}$ could favor lianas in two non-mutually exclusive ways. First, elevated $\mathrm{CO}_{2}$ may increase tree growth, productivity and mortality, ultimately creating more treefall gaps and thus indirectly favoring lianas over 
trees (Phillips \& Gentry [28] , but see Clark et al. [6] ). Second, elevated $\mathrm{CO}_{2}$ could favor lianas directly by increasing their growth and fecundity more than trees (Hättenschwiler \& Körner [15] , Mohan et al. [26] ), thereby increasing relative liana size and recruitment. Indeed, Wright and Calderón ([47] ) reported a strong relative increase in liana flower production compared to trees on Barro Colorado Island ( $\mathrm{BCl})$, Panama, where liana density and tree infestation have increased considerably over the past 40 yrs (Ingwell et al. [18] ). Liana seedling recruitment increased 500 percent over a 6-yr period (1993-1999) in an intact forest in the Central Amazon, whereas tree and palm/herb seedling recruitment decreased 62 percent and 85 percent, respectively (Benítez-Malvido \& Martínez-Ramos [2] , see also Chave et al. [4] ).

Another potential and non-mutually exclusive explanation of increasing liana abundance and biomass in Neotropical forests is through long-distance clonal colonization. Compared to trees, lianas have a much greater ability to produce multiple clonal ramets (e.g., Peñalosa [27] , Putz [30] , Schnitzer et al. [37] , [41] , Gerwing [13] ). For example, nearly one-third of the $\mathrm{ca} 67,500$ liana stems ( $\geq 1 \mathrm{~cm}$ diameter) rooted in the Barro Colorado Island (Panama) 50 ha plot were still connected vegetative offshoots of larger rooted lianas (Schnitzer et al. [40] ). Furthermore, large lianas can extend through the canopy more than $500 \mathrm{~m}$ from their initial rooting point, giving them the capacity to disperse clonal stems far away from the mother stem after it is pulled to the ground in tree- or branch-falls (Putz [30] ). Lianas that fall from the canopy can divide into numerous ramets that re-root and become independent from their 'mother' genet (Putz [30], Peñalosa [27], Schnitzer et al. [37] , [41] , Gerwing [13] ). In some cases, only part of the liana stem will fall to the ground and re-root, while the mother genet remains in the forest canopy (Putz [30] , Schnitzer et al. [40] ). Clonal colonization may be particularly common in treefall gaps and other disturbances, where up to 90 percent of liana stems can survive the fall of their host tree, and many of these stems will resprout copiously, re-root, and eventually climb back to the forest canopy (Putz [30] , Schnitzer et al. [37] , [41] ). If the level of disturbance in tropical forests increases due to greater intensity of seasonal droughts, higher atmospheric $\mathrm{CO}_{2}$, and land-use changes (reviewed by Schnitzer \& Bongers [35] ), the number of lianas that recruit as clonal stems will also likely increase, possibly explaining the pattern of increasing liana abundance and biomass in Neotropical forests.

We examined the change in liana abundance and basal area in old-growth and selectively logged forests utilizing a long-term liana demographic study at La Selva Biological Station in Costa Rica. Increasing intensity of seasonal drought and elevated nighttime temperatures are thought to have reduced tree growth at La Selva (Clark et al. [6] ), but little is known about the change in lianas at this site. We followed the fate of permanently tagged lianas for 8 yrs to test whether: (1) liana abundance and basal area are increasing in a tropical wet forest; (2) the increase is being driven by increased recruitment, decreased mortality, or a combination of these factors; and (3) long-distance clonal colonization explains the increase in liana abundance and basal area.

\section{Methods}

\section{Study site}

We conducted the study at La Selva Biological Station, a 1600 ha forest reserve in northeastern Costa Rica (1025'52" N, 8400'12" W; McDade \& Hartshorn [25] ). La Selva is a lowland tropical wet forest (Holdridge et al. [17] ) that receives approximately $4000 \mathrm{~mm}$ of rainfall annually, with no month receiving less than $150 \mathrm{~mm}$ on average (Sanford et al. [32] ). Mean monthly temperatures vary little during the year and range from 24.7 to $27.1^{\circ} \mathrm{C}$ (McDade \& Hartshorn [25] ). The forest at La Selva is primarily old-growth, but it also has areas of young secondary forest as well as small tracts (ca $100 \mathrm{ha}$ ) that were formerly old-growth forest, but were selectively logged beginning around 50 yrs ago and large trees were harvested up until 1981 when those areas were acquired by the La Selva Biological Station (McDade \& Hartshorn [25] , Mascaro et al. [23] , D.A. Clark, pers. comm., D.B. Clark, pers. comm.). Soils are lava-derived ultisols, highly leached, and rich in organic matter (Sollins 
et al. [44] ). For more information on La Selva see McDade et al. ([24] ) and on our long-term liana sampling plots see Mascaro et al. ([23] ).

\section{Sampling procedure}

In December 1998, we established nine, $24 \times 36 \mathrm{~m}$ (0.086 ha) permanent plots in a stratified random design. Six plots (OG 1-6) were in old-growth forest and three plots (SL 1-3) in forests that had been selectively logged as recently as 1981 (Mascaro et al. [23] , D.A. Clark pers. comm.). Four of the plots (SL 1, SL 2, SL 3, and OG 3) are on the Matabuey soil consociation, whereas five plots (OG 1, OG 2, OG 4, OG 5, and OG 6) are on the Jaguar soil consociation (Sollins et al. [44] ), but these two soil types appear to have no significant chemical differences between them (Sancho \& Mata [31]).

In January 1999, we tagged, mapped, measured the diameter, and identified to species all freestanding and climbing liana individuals $\geq 0.5 \mathrm{~cm}$ in diameter $(1.3 \mathrm{~m}$ from the root) that were rooted in the plots (methods follow Gerwing et al. [14] , Schnitzer et al. [42] ). Liana stems that were not visibly connected to any other individual were considered to be apparent genets (individual lianas that appeared to be genetically distinct individuals; Schnitzer et al. [38] ). Individuals that were still attached to the mother stem were considered vegetative clones (ramets), and were not included in our estimates of liana abundance and basal area (follows Putz [30] ). We did not excavate lianas that may have been connected below ground, and thus we treated separately rooted lianas that were not attached to another individual in the census as distinct apparent genets (follows Gerwing et al. [14] , Schnitzer et al. [38] , [42] ).

In July 2002 and in January 2007, we remeasured the diameter of all lianas in the plots, and tagged, mapped, and identified all new lianas that recruited into the $0.5 \mathrm{~cm}$ minimum diameter size class. We analyzed the data both inclusive and exclusive of the $0.5 \mathrm{~cm}$ stems, but we report stems $\geq 1 \mathrm{~cm}$ diameter to make our data more comparable to other studies (recommended by Gerwing et al. [14] , Schnitzer et al. [42] ), as well as to focus on the more stable liana community comprised of larger stems, which have much lower turnover than stems $<1 \mathrm{~cm}$ diameter. We classified clonal colonization as lianas that met the following three criteria: (1) were present in the census in 2007, but absent in 1999 or 2002; (2) had clearly entered and rooted in the plot as a part of a stem originating from above or from outside the plot; and (3) were $\geq 2 \mathrm{~cm}$ diameter in 2007. Our size criterion was based on the finding that lianas $\geq 2 \mathrm{~cm}$ in diameter have an $85-90$ percent chance of being present in the canopy in other tropical forests (Kurzel et al. [19] ).

In November 2007, we collected initial data on the trees and shrubs within the plots. We measured tree, shrub, and palm diameters at breast height ( $\mathrm{dbh}$ ), $1.3 \mathrm{~m}$ from the ground of all individuals $\geq 1 \mathrm{~cm}$ dbh, which we used to calculate tree/shrub basal area and relative liana abundance and basal area in the nine plots. We excluded palms and restricted our study to woody species.

\section{Analysis}

We compared the change in liana stem number and total basal area from 1999 to 2007 for lianas $\geq 1 \mathrm{~cm}$ diameter using the Wilcoxon Signed-Rank Test paired by year and with plot as the unit of replication $(\mathrm{N}=9)$ (follows Londré \& Schnitzer [22]). We used the same test to compare the net change in liana stem number and total basal area over the 8-yr period with and without the lianas that recruited via vegetative reproduction in all forests combined and in the old-growth and selectively logged forests separately. The results of the 2002 census are reported in Mascaro et al. ([23] ).

\section{Results}

We tagged and included a total of 1371 lianas that were present in either the 1999 or 2007 census; 487 individuals were present in both censuses. In 2007, after the first census of free-standing vegetation, there 
were: 2835 trees and shrubs, 144 palms, and 873 lianas ( 3852 woody stems and palms $\geq 1 \mathrm{~cm}$ diameter). Mean tree and shrub stem number combined per plot was 315 ( $\pm 19.52 \mathrm{SE}$ ), mean palm number per plot was 16 $( \pm 1.91)$, and mean liana stem number per plot was $69( \pm 3.45)$. Lianas composed 18 percent of all woody stems $\geq 1 \mathrm{~cm}$ (17\% including palms). Mean tree and shrub basal area per plot was $30.5( \pm 2.86) \mathrm{m}^{2} / \mathrm{ha}$, and mean liana basal area per plot was $1.00( \pm 0.08) \mathrm{m}^{2} / \mathrm{ha}$-representing only 3.2 percent of the total woody plant basal area.

\section{Change in liana basal area}

Per-plot basal area (BA) for lianas $\geq 1 \mathrm{~cm}$ increased significantly from 1999 until 2007 and was higher in eight of the nine plots $(P=0.037$, $t$-ratio $=2.05, d f=8)$ (Fig. $1 \mathrm{~A}$ ). Median liana $B A$ in the nine plots was 0.85 (range: $0.57-$ 1.10) $\mathrm{m}^{2} /$ ha in 1999 and 1.04 (range: 0.59-1.30) $\mathrm{m}^{2} /$ ha in 2007; a 22 percent increase over the 8-yr period. Mean liana BA was $0.86( \pm 0.07 \mathrm{SE}) \mathrm{m}^{2} / \mathrm{ha}$ in 1999 and $1.00( \pm 0.08) \mathrm{m}^{2} /$ ha in 2007; a 16 percent increase over the 8-yr period. Liana clonal colonization from outside of the plot added a total of $1.10 \mathrm{~m}^{2} / \mathrm{ha}$ BA into the nine plots (combined) over the 8-yr period, which constituted 60 percent of the increase in BA of new recruits (Figs. 2 $A$ and $B)$.

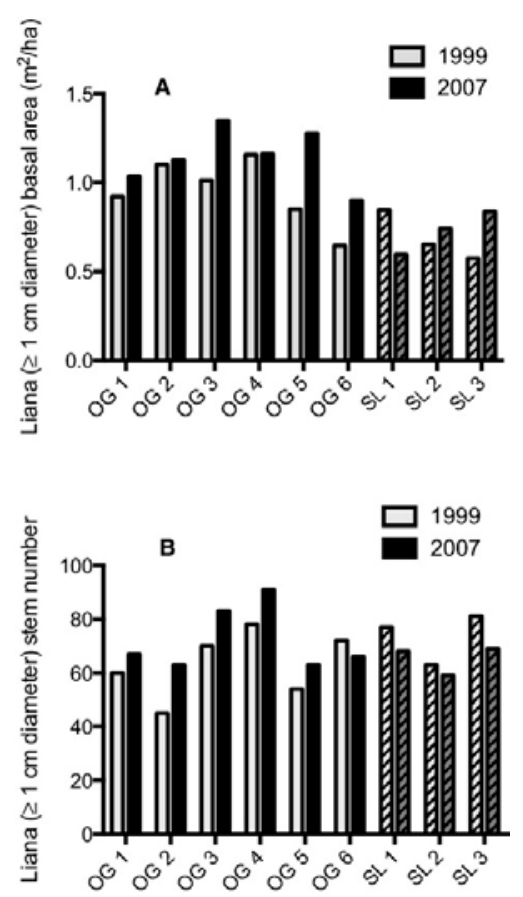

Figure 1. Per plot basal area (A) and stem number (B) for lianas $\geq 1 \mathrm{~cm}$ diameter in 1999 and 2007 in nine, $24 \times 36 \mathrm{~m}$ plots at La Selva Biological Station, Costa Rica. The increase in basal area was significant in the oldgrowth plots, but not in the selectively logged plots. The increase in liana stem number was significant in the old-growth plots, but not in the selectively logged plots. Plots labeled OG 1-6 (solid bars) were located in oldgrowth forest and plots labeled SL 1-3 (hatched bars) were in selectively logged forest. Liana basal area was higher in all six of the old-growth plots (BA in OG 4 was higher in 2007 than in $1999-1.157 \mathrm{~m}^{2} / \mathrm{ha}$ in 1999 vs. $1.61 \mathrm{~m}^{2} /$ ha in 2007) and liana stem number was higher in five of the six old-growth forest plots. 

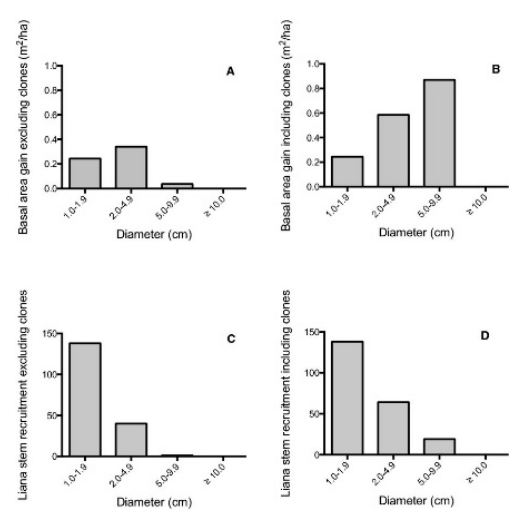

Figure 2. Liana basal area and stem recruitment from 1999 to 2007 of all stems combined in nine, $24 \times 36 \mathrm{~m}$ forest plots at La Selva Biological Station, Costa Rica. Six of the plots were in old-growth and three were in selectively logged forest. Panels A and B represent the total amount of liana basal area that recruited into the plots during the 8-yr period excluding and including clonal colonization, respectively. Panels $C$ and $D$ represent the total number of lianas that recruited into the plots during the 8-yr period excluding and including clonal colonization, respectively.

Liana BA increased significantly from 1999 to 2007 and in all six old-growth plots $(P=0.02, t$-ratio $=2.76, d f=5)$. Median liana BA increased from 0.97 (range: 0.65-1.16) in 1999 to 1.14 (range: 0.90-1.25) in 2007; a 17.5 percent increase over the 8-yr period. Mean liana BA of the old-growth forest sites was $0.95( \pm 0.07) \mathrm{m}^{2} / \mathrm{ha}$ in 1999 and $1.14( \pm 0.07) \mathrm{m}^{2} /$ ha in 2007; a 20 percent increase over the 8-yr period. In the selectively logged forests $(\mathrm{N}=3)$, however, liana BA did not change significantly over the 8 -yr period $(P=0.58, t$-ratio $=0.22, d f=2)$.

\section{Change in liana abundance}

Liana abundance did not change over the $8 \mathrm{yrs}$, and only five of the nine forest plots had more lianas in 1999 than in $2007(P=0.56$, t-ratio = 0.16, df = 8; Fig. 1 B). Median liana abundance in 1999 and 2007 were 72.0 (range: 45-83) and 67.0 (range: 59-91), and mean liana abundance in 1999 and 2007 were 69.2 ( \pm 4.3 ) and 69.9 $( \pm 3.5)$, respectively. Forty-two lianas recruited via clonal colonization from outside of the plots, comprising 19 percent of new recruits $\geq 1 \mathrm{~cm}$ diameter (Figs. $2 \mathrm{C}$ and $\mathrm{D}$ ).

Restricting the comparison to the old-growth plots revealed that liana abundance ( $\geq 1 \mathrm{~cm}$ diameter) was significantly higher in 2007 compared with 1999 in five of the six old-growth plots $(P=0.022$, t-ratio $=2.66$, $d f=5$ ) (Fig. 1 B). Median per plot liana abundance in the old-growth plots was 71 (range: 45-83) in 1999 and 66.5 (range: 63-91) in 2007. Mean per plot liana abundance was $67.0( \pm 5.0)$ stems per plot in 1999 and 72.2 $( \pm 4.8)$ in 2007; a 14 percent increase. Liana abundance in the selectively logged forest did not change significantly from 1999 until $2007(P=0.58$, t-ratio $=0.22$, df $=2$ ) (Fig. 1 B).

\section{Liana dynamics (mortality and recruitment)}

Liana mortality was high over the 8-yr period; 41.3 percent (248 stems total) of the individuals died, and this mortality was concentrated $(51.2 \%)$ in the smallest size class $(1.0-1.9 \mathrm{~cm})$. Mean per plot recruitment, however, balanced mortality for the smallest size class; an average of 15 small stems recruited into each plot, whereas 14 small stems per plot died by 2007 (Figs. 3 A and B). The greatest increase in liana BA was in the larger size classes ( $\geq 2 \mathrm{~cm}$ diameter), and was driven primarily by clonal colonization from relatively large individuals that originated from outside the plot (Figs. $2 \mathrm{~A}$ and $\mathrm{B}$ and $3 \mathrm{C}$ and $\mathrm{D}$ ). In the old-growth forest, total recruitment for lianas $\geq 1 \mathrm{~cm}$ diameter was 15 percent higher than mortality (169 stems vs. 147, respectively). In the selectively logged forest, mortality of lianas $\geq 1 \mathrm{~cm}$ diameter was twice as high as recruitment (101 vs. 52 stems, respectively). 

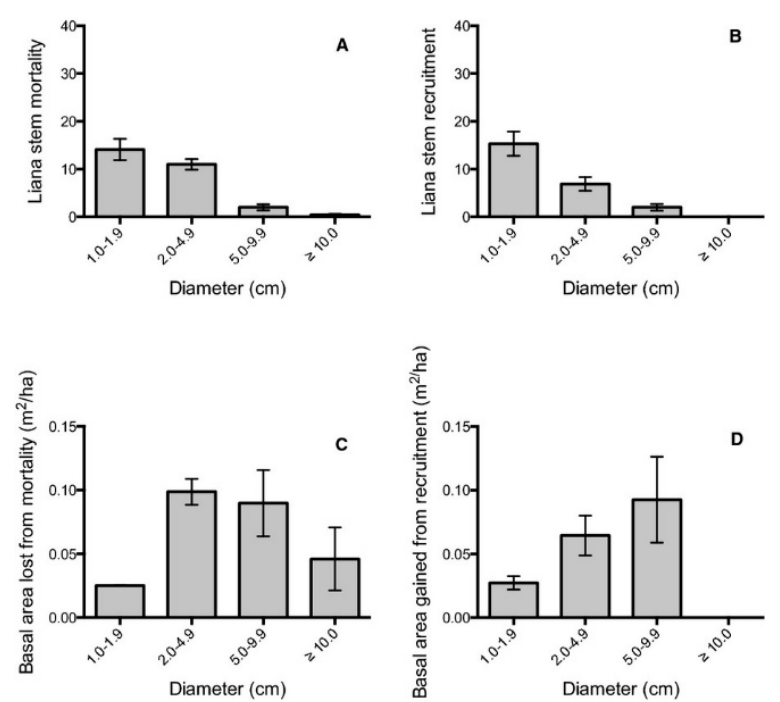

Figure 3. Mean liana mortality (A), recruitment (B), basal area lost (C), and basal area gained (D) of all stems from 1999 to 2007 over four size classes in nine, $24 \times 36$ m forest plots at La Selva Biological Station, Costa Rica. Six of the plots were in old-growth and three were in selectively logged forest. Mean values were based on all lianas in four discrete size classes (including clonal colonization for size classes $\geq 2 \mathrm{~cm}$ diameter) using each plot as a replicate. Error bars represent one standard error.

\section{Discussion}

Our findings support the hypothesis that lianas are increasing in abundance and basal area, and probably also biomass, in the old-growth forest at La Selva. The increase in lianas at La Selva is consistent with similar reports of liana increases in other old-growth Neotropical forests (reviewed by Schnitzer \& Bongers [35] ). Mean liana abundance increased 15 percent and basal area increased 20 percent over the 8-yr period in the old-growth forest. The largest increases in liana basal area between 1999 and 2007 were in the $2.0-4.9 \mathrm{~cm}$ and $5.0-9.9 \mathrm{~cm}$ size classes and were due mostly (60\%) to long-distance clonal colonization (Figs. 2 and 3 ), supporting the hypothesis that long-distance clonal colonization is a driver of increasing liana basal area. Lianas have a far greater capacity for long-distance clonal colonization than trees (Schnitzer et al. [41] ), and lianas are increasing in Neotropical forests relative to trees (Schnitzer \& Bongers [35] ). Thus, long-distance clonal colonization provides a compelling explanation for the increase in liana abundance and basal area at La Selva as well as in many other tropical forests (Peñalosa [27] , Putz [30] , Gerwing [13] , Schnitzer et al. [40] ).

\section{Long-distance clonal colonization}

Lianas appeared to colonize the study plots by falling from the canopy and re-rooting following tree- and branch-falls, and there was evidence of tree-falls of varying ages in the old-growth forest during the 2007 census (S. R. Yorke, pers. obs.). The ability of lianas to grow long distances from the initial rooting point and to extend through dozens of tree crowns before falling to the forest floor and re-rooting (Peñalosa [27] , Putz [30] ) enables lianas to propagate clonally far from their point of origin. We term this phenomenon long-distance clonal colonization and suggest that it may be an important form of clonal spread by lianas in tropical forests (see also Peñalosa [27] , Putz [30] ). Long-distance clonal colonization may occur in one of two ways. First, a disturbance (e.g., tree or branch fall) can cause a clean break of a large liana branch from its parent and, once on the ground; it re-roots and grows back to the canopy (Putz [30] ). Second, lianas may fall to the forest floor, reroot, and produce multiple liana stems while still connected to the parent stem, which remains in the forest canopy (Putz [30] , Schnitzer et al. [41] ). This latter method of colonization may be particularly effective in allowing lianas to proliferate if the parent stem supplies carbohydrates, water, and nutrients, giving the clonal propagules the resources necessary to become independently rooted lianas that can climb back up to the 
canopy, even at relatively small stem diameters (Kurzel et al. [19] ). At some future point, the connection between the clonal propagules and the parent stem may disintegrate, resulting in multiple separate ramets that become independent 'apparent genets' (sensu Schnitzer et al. [38] , [40] ). Because of the ability of lianas to course through multiple tree crowns and to resprout copiously in tropical forests in many parts of the world (e.g., Putz [30] , Schnitzer et al. [41] , Garrido-Pérez et al. [12] ), long-distance clonal colonization is likely to be a common method of liana colonization. Furthermore, if disturbance has increased in tropical forests then longdistance clonal colonization may have also increased, which may contribute to the relative increase in lianas in tropical forests.

Long-distance clonal colonization along the soil surface may also contribute to increasing liana abundance and biomass. Lianas may extend horizontally across the forest floor and establish new rooting points long distances from the original rooting location. At each rooting point, the liana will often create a new stem, and thus a single individual snaking along the forest floor has the capacity to become multiple independently rooted clones, each separated by dozens of meters (Peñalosa [27] , Putz [30] ). In the selectively logged forest, we did not find direct evidence of treefalls, but two plots had clonal colonists, suggesting that lianas recruit via long-distance clonal colonization even in the absence of treefalls.

\section{Liana changes in selectively logged and old-growth forests}

Liana abundance decreased in all three selectively logged forest plots over the 8-yr period-a noticeable deviation from the pattern of liana increases in five of the six old-growth forest plots. Previous logging activity at La Selva within 20 yrs of our initial observations may have increased liana abundance because lianas recruit rapidly into treefall and logging gaps (e.g., Putz [30] , Babweteera et al. [1] , Schnitzer et al. [37] , [41] , Foster et al. [11] ). Eventually, however, liana mortality should reduce the number of lianas with the decrease in light, and the decrease in liana abundance in all three selectively logged plots and increase in BA in two of the three selectively logged forests may be a natural successional pattern of declining liana abundance and increasing basal area after logging (Dewalt et al. [9] , Letcher \& Chazdon [21] ). Perhaps, the drivers that caused increases in liana abundance and basal area in the old-growth forest were also operating in the selectively logged forests, but were subordinate to the successional patterns of decreasing lianas and increasing basal area. We cannot evaluate this hypothesis with our dataset.

In the old-growth forest, decreasing dry season rainfall and increasing temperature may drive the increase in lianas - both factors combined increase evapotraspirative demand (Schnitzer \& Bongers [35] ). Lianas perform relatively better than trees under higher evapotranspirative demand (e.g., Schnitzer [33] ), and even though rainfall at La Selva is still relatively high during the dry season (>100 $\mathrm{mm}$ per month), even slight changes in rainfall and temperature may significantly affect plant performance (Clark et al. [6] ). For example, over the past 24 yrs, tree growth at La Selva was significantly lower during periods of reduced dry season rainfall and increased temperature (Clark et al. [6] ). These changes in climate may also favor the lianas of La Selva by increasing tree mortality and treefall gap formation, which promotes liana regeneration, density, and diversity (Schnitzer et al. [37] , [40] ). Increasing gap formation also increases long-distance clonal colonization, which appears to be a strong contributor to liana increases at La Selva.

The increase in lianas may be a permanent directional change in tropical forests, or it may be an oscillating trend that would later be balanced by liana decreases. It is possible that we recorded a natural fluctuation in liana abundance, but we have not monitored these plots for long enough to detect a corresponding decrease in abundance. If this possibility is true, however, we should then expect to see a greater balance between large liana recruitment and mortality at the plot level, which is not supported by this study or by other studies that report increased liana abundance and basal area (Phillips et al. [29] , Chave et al. [4] , Schnitzer et al. [40] ), leaf litter production (Wright et al. [48] ), liana floral production (Wright \& Calderón [47] ), and levels of tree 
infestation by lianas (Ingwell et al. [18] ). Furthermore, we selected the plots randomly and without any preconceived notion of forest structure (e.g., we did not avoid gaps); hence, if there are cyclical changes in liana abundance with gap-phase regeneration we would expect to have all phases represented in our plots. If the increases in liana abundance and basal area documented here and elsewhere continue into the future, they indicate marked changes in forest structure (Schnitzer \& Bongers [35] ), particularly at La Selva and other wet forests where liana abundance and basal area are relatively low in comparison to more seasonal forests (Mascaro et al. [23] , Schnitzer [33] , Dewalt et al. [8] ).

As lianas increase, they have a greater competitive effect on trees, and even a small number of lianas in a tree can reduce its growth (e.g., Schnitzer \& Carson [36] , Tobin et al. [45] ). When liana abundance becomes high, tree mortality increases substantially (Ingwell et al. [18] ), thus increasing forest turnover and possibly leading to a positive feedback between increasing lianas and tree mortality (Phillips \& Gentry [28] ). Lianas and fastgrowing pioneer trees species with low wood density capitalize on the resulting treefall gaps (Putz [30], Phillips \& Gentry [28] , Schnitzer et al. [37] , [41] ), and together they may displace slower-growing, shade-tolerant tree species, which have higher wood density (Schnitzer et al. [37] , van der Heijden \& Phillips [16] , Schnitzer \& Carson [36] ). If the trend of increasing lianas continues, the liana-mediated restructuring of tree regeneration and survival may ultimately lead to lower overall carbon sequestration in tropical forests because the amount of carbon in lianas and pioneer trees does not offset that in displaced high wood density, shade-tolerant species (Laurance et al. [20] , Phillips et al. [29] , Schnitzer \& Bongers [34] , van der Heijden \& Phillips [16] , Schnitzer \& Bongers [35] ). Consequently, our findings of increasing liana abundance and basal area in the old-growth forests at La Selva represent an important structural change in this tropical forest, which has potentially serious implications for tree community composition and forest carbon dynamics.

\section{Acknowledgments}

We thank Laura Ingwell and Orlando Vargas for help with data collection, and David Clark and Deborah Clark provided helpful comments on land-use history at La Selva, as well as on an early draft of the manuscript. This study was supported by the University of Wisconsin - Milwaukee Research Growth Initiative program, the University of Wisconsin - Milwaukee Center for Latin American and Caribbean Studies, NSF DEB-0613666, NSF DEB-0845071 to SAS, DEB-9527729 and DEB-0212054 to WPC, and an Andrew Mellon Foundation Research Awards in Tropical Biology to WPC and SAS. The Organization for Tropical Studies and the staff at La Selva Biological Station provided logistic support.

\section{Literature Cited}

1. Babweteera, F., A. Plumptre, and J. Obua. 2000. Effect of gap size and age on climber abundance and diversity in Budongo Forest Reserve, Uganda. Afr. J. Ecol. 38: 230- 237.

2. Benítez-Malvido, J., and M. Martínez-Ramos. 2003. Impact of forest fragmentation on understory plant species richness in Amazonia. Conserv. Biol. 17: 389- 400.

3. Cai, Z.-Q., S. A. Schnitzer, and F. Bongers. 2009. Seasonal differences in leaf-level physiology give lianas a competitive advantage over trees in a tropical seasonal forest. Oecologia 161: 25- 33.

4. Chave, J., J. Olivier, F. Bongers, P. Chatelet, P. M. Forget, P. van der Meer, N. Norden, B. Riera, and P. CharlesDominique. 2008. Above-ground biomass and productivity in a rain forest of eastern South America. J. Trop. Ecol. 24: 355- 366.

5. Clark, D. B., and D. A. Clark. 1990. Distribution and effects on tree growth of lianas and woody hemiepiphytes in a Costa Rican tropical wet forest. J. Trop. Ecol. 6: 321- 331.

6. Clark, D. B., D. A. Clark, and S. F. Oberbauer. 2010. Annual wood production in a tropical rain forest in NE Costa Rica linked to climatic variation but not to increasing $\mathrm{CO}_{2}$. Glob. Change Biol. 16: 747- 759 . 
7. Dalling, J. W., S. A. Schnitzer, K. Harms, R. John, S. Mangan, C. Baldeck, S. P. Hubbell, and E. Lobo. 2012. Resource-based habitat partitioning in a neotropical liana community. J. Ecol. 100: 1174- 1182.

8. Dewalt, A. J., S. A. Schnitzer, J. Chave, F. Bongers, R. J. Burnham, Z.-Q. Cai, G. Chuyong, D. B. Clark, C. E. N. Ewango, J. J. Gerwing, E. Gortaire, T. Hart, G. Ibarra-Manríquez, K. Ickes, D. Kenfack, M. J. Macía, J. R. Makana, J. Mascaro, M. Martínez-Ramos, S. Moses, H. C. Muller-Landau, M. P. E. Parren, N. Parthasarathy, D. R. Pérez-Salicrup, F. E. Putz, H. Romero-Saltos, and D. Thomas. 2010. Annual rainfall and seasonality predict pan-tropical patterns of liana density and basal area. Biotropica 42: 309- 317.

9. Dewalt, S. J., S. A. Schnitzer, and J. S. Denslow. 2000. Density and diversity of lianas along a chronosequence in a central Panamanian lowland forest. J. Trop. Ecol. 16: 1- 19.

10. Enquist, B. J., and C. A. F. Enquist. 2011. Long-term change within a Neotropical forest: Assessing differential functional and floristic responses to drought and past disturbances. Glob. Change Biol. 17: 1408- 1424.

11. Foster, J. R., P. A. Townsend, and C. E. Zganjar. 2008. Spatial and temporal patterns of gap dominance by low-canopy lianas detected using EO-1 Hyperion and Landsat Thematic Mapper. Remote Sens. Environ. 112: 2104- 2117.

12. Garrido-Pérez, E. I., J. M. Dupuy, R. Durán-García, G. Gerold, S. A. Schnitzer, and M. UcanMay. 2008. Structural effects of lianas and hurricane Wilma on trees in Yucatan peninsula, Mexico. J. Trop. Ecol. 24: 559- 562.

13. Gerwing, J. J. 2004. Life history diversity among six species of canopy lianas in an old-growth forest of the eastern Brazilian Amazon. For. Ecol. Manage. 190: 57- 72.

14. Gerwing, J. J., S. A. Schnitzer, R. J. Burnham, F. Bongers, J. Chave, S. J. DeWalt, C. E. N. Ewango, R. Foster, D. Kenfack, M. Martinez-Ramos, M. Parren, N. Parthasarathy, D. R. Perez-Salicrup, F. E. Putz, and D. W. Thomas. 2006. A standard protocol for liana censuses. Biotropica 38: 256- 261.

15. Hättenschwiler, S., and C. Körner. 2003. Does elevated $\mathrm{CO}_{2}$ facilitate naturalization of the nonindigenous Prunus laurocerasus in Swiss temperate forests? Funct. Ecol. 17: 778- 785.

16. van der Heijden, G. M. F., and O. L. Phillips. 2009. Environmental effects on Neotropical liana species richness. J. Biogeogr. 36: 1561-1572.

17. Holdridge, L. R., W. C. Grenke, W. H. Hatheway, T. Liang, and J. A. Tosi, Jr. 1971. Forest Environments in Tropical Life Zones. Pergamon Press, New York.

18. Ingwell, L. L., S. J. Wright, K. K. Becklund, S. P. Hubbell, and S. A. Schnitzer. 2010. The impact of lianas on 10 years of tree growth and mortality on Barro Colorado Island, Panama. J. Ecol. 98: 879- 887.

19. Kurzel, B. P., S. A. Schnitzer, and W. P. Carson. 2006. Predicting liana crown location from stem diameter in three Panamanian lowland forests. Biotropica 38: 262- 266.

20. Laurance, W. F., D. Perez-Salicrup, P. Delamonica, P. M. Fearnside, S. D'Angelo, A. Jerozolinski, L. Pohl, and T. E. Lovejoy. 2001. Rain forest fragmentation and the structure of Amazonian liana communities. Ecology 82: 105- 116.

21. Letcher, S. G., and R. L. Chazdon. 2009. Lianas and self-supporting plants during tropical forest succession. For. Ecol. Manage. 257: 2150- 2156.

22. Londré, R. A., and S. A. Schnitzer. 2006. The distribution of lianas and their change in abundance in temperate forests over the past 45 years. Ecology 87: 2973- 2978.

23. Mascaro, J., S. A. Schnitzer, and W. P. Carson. 2004. Liana diversity, abundance, and mortality in a tropical wet forest in Costa Rica. For. Ecol. Manage. 190: 3- 14.

24. L. A. McDade, K. S. Bawa, H. A. Hespenheide, and G. S. Hartshorn. (Eds.), 1994. La Selva: Ecology and Natural History of a Neotropical Rain Forest. The University of Chicago Press, Chicago.

25. McDade, L. A., and G. S. Hartshorn. 1994. La Selva Biological Station. In L. A. McDade, K. S. Bawa, H. A. Hespenheide, and G. S. Hartshorn (Eds.). La Selva: Ecology and Natural History of a Neotropical Rain Forest, pp. 6-14. The University of Chicago Press, Chicago. 
26. Mohan, J. E., L. H. Ziska, W. H. Schlesinger, R. B. Thomas, R. C. Sicher, K. George, and J. S. Clark. 2006. Biomass and toxicity responses of poison ivy (Toxicodendron radicans) to elevated atmospheric $\mathrm{CO}_{2}$. Proc. Nat. Acad. Sci. USA 103: 9086- 9089.

27. Peñalosa, J. 1984. Basal branching and vegetative spread in two tropical rain forest Lianas. Biotropica 16: 8.

28. Phillips, O. L., and A. H. Gentry. 1994. Increasing turnover through time in tropical forests. Science 263: 954-958.

29. Phillips, O. L., R. V. Martinez, L. Arroyo, T. R. Baker, T. Killeen, S. L. Lewis, Y. Malhi, A. M. Mendoza, D. Neill, P. N. Vargas, M. Alexiades, C. Ceron, A. Di Fiore, T. Erwin, A. Jardim, W. Palacios, M. Saldias, and B. Vinceti. 2002. Increasing dominance of large lianas in Amazonian forests. Nature 418: 770- 774.

30. Putz, F. E. 1984. The natural history of lianas on Barro Colorado Island, Panama. Ecology 65: 1713- 1724.

31. Sancho, F., and R. Mata. 1987. Estudio detallado de suelos. Estación Biológica "La Selva." Report, Organization for Tropical Studies, San José, Costa Rica.

32. Sanford, R. L. J., P. Paaby, J. C. Luvall, and E. Phillips. 1994. Climate, Geomorphology, and Aquatic Systems. In L. A. McDade, K. S. Bawa, H. A. Hespenheide, and G. S. Hartshorn (Eds.). La Selva: Ecology and Natural History of a Neotropical Rain Forest, pp. 19- 33. The University of Chicago Press, Chicago.

33. Schnitzer, S. A. 2005. A mechanistic explanation for global patterns of liana abundance and distribution. Am. Nat. 166: 262- 276.

34. Schnitzer, S. A., and F. Bongers. 2002. The ecology of lianas and their role in forests. Trends Ecol. Evol. 17: 223-230.

35. Schnitzer, S. A., and F. Bongers. 2011. Increasing liana abundance and biomass in tropical forests: Emerging patterns and putative mechanism. Ecol. Lett. 14: 397- 406.

36. Schnitzer, S. A., and W. P. Carson. 2010. Lianas suppress tree regeneration and diversity in treefall gaps. Ecol. Lett. 13: 849-857.

37. Schnitzer, S. A., J. W. Dalling, and W. P. Carson. 2000. The impact of lianas on tree regeneration in tropical forest canopy gaps: Evidence for an alternative pathway of gap-phase regeneration. $J$. Ecol. 88: 655- 666.

38. Schnitzer, S. A., S. J. DeWalt, and J. Chave. 2006. Censusing and measuring lianas: A quantitative comparison of the common methods. Biotropica 38: 581- 591.

39. Schnitzer, S. A., M. Kuzee, and F. Bongers. 2005. Disentangling above-and below-ground competition between lianas and trees in a tropical forest. J. Ecol. 93: 1115- 1125.

40. Schnitzer, S. A., S. A. Mangan, J. W. Dalling, C. A. Baldeck, S. P. Hubbell, A. Ledo, H. Muller-Landau, M. F. Tobin, S. Aguilar, D. Brassfield, A. Hernandez, S. Lao, R. Perez, O. Valdez, and S. R. Yorke. 2012. Liana abundance, diversity, and distribution on Barro Colorado Island, Panama. PLoS ONE 7: e52114. doi:10.1371/journal.pone.0052114.

41. Schnitzer, S. A., M. P. E. Parren, and F. Bongers. 2004. Recruitment of lianas into logging gaps and the effects of pre-harvest climber cutting in a lowland forest in Cameroon. For. Ecol. Manage. 190: 87- 98.

42. Schnitzer, S. A., S. Rutishauser, and S. Aguilar. 2008. Supplemental protocol for liana censuses. For. Ecol. Manage. 255: 1044- 1049.

43. Schnitzer, S. A., S. J. Wright, and F. Bongers. 2011. Community and ecosystem ramifications of increasing lianas in neotropical forests. Plant Signal. Behav. 6: 598-600.

44. Sollins, P., F. M. Sancho, R. C. Mata, and R. L. J. Sanford. 1994. Soils and Soil Process Research. In L. A. McDade, K. S. Bawa, H. A. Hespenheide, and G. S. Hartshorn (Eds.). La Selva: Ecology and Natural History of a Neotropical Rain Forest, pp. 34- 53. The University of Chicago Press, Chicago.

45. Tobin, M. F., A. J. Wright, S. A. Mangan, and S. A. Schnitzer. 2012. Lianas have a greater competitive effect than trees of similar biomass on tropical canopy trees. Ecosphere 3: 20. http://dx.doi.org/10.1890/ES11$\underline{00322.1}$ 
46. Toledo-Aceves, T., and M. D. Swaine. 2008. Effect of lianas on tree regeneration in gaps and forest understorey in a tropical forest in Ghana. J. Veg. Sci. 19: 717- U770.

47. Wright, S. J., and O. Calderón. 2006. Seasonal, El Nino and longer term changes in flower and seed production in a moist tropical forest. Ecol. Lett. 9: 35- 44.

48. Wright, S. J., O. Calderon, A. Hernandez, and S. Paton. 2004. Are lianas increasing in importance in tropical forests? A 17-year record from Panama. Ecology 85: 484- 489.

49. Zhu, S.-D., and K.-F. Cao. 2010. Contrasting cost-benefit strategy between lianas and trees in a tropical seasonal rain forest in southwestern China. Oecologia 163: 591- 599. 